\title{
REBUILDING OF RAT INTESTINAL MUCOUS EPITHELIUM IN PRENATAL ONTOGENESIS
}

\author{
Radomíra Vagnerová, Tomáš Kučera
}

Institute of Histology and Embryology, $1^{\text {st }}$ Faculty of Medicine, Charles University, Albertov 4, 12801 Prague 2, Czech Republic

e-mail: radomira.vagnerova@lf1.cuni.cz

Received: September 20, 2004

Key words: Rat intestinal epithelium/Prenatal differentiation/Apoptosis

Morphological differentiation of the intestinal epithelium in the laboratory rat occurs between the $16^{\text {th }}$ and $21^{\text {st }}$ day of prenatal development. The pseudostratified epithelium is rebuilt into simple epithelium of the future lining. A characteristic sign of this rebuilding is formation of primitive folds, villi and intraepithelial vacuoles coresponding in submicroscopic picture with a secondary luminization. On the tips of folds and villi groups of cells released from the epithelium are observed. In these cells expression of activated caspase- 3 confirms the presence of apoptosis in the process of cell death during epithelium rebuilding.

\section{INTRODUCTION}

During maturation of the intestinal epithelium nondifferentiated pseudostratified epithelium is transformed into simple epithelium ${ }^{1,2}$. The epithelial proliferation and differentiation is accompanied by several signs of programmed cell death including apoptosis.

\section{MATERIAL AND METHODS}

Rat embryos from the $16^{\text {th }}$ to $21^{\text {st }}$ day were processed for light and electron microscopy; semithin sections and paraffin serial sections were prepared. Apoptosis was confirmed by the presence of activated caspase- 3 as the key enzyme of the executing phase of apoptosis.

\section{RESULTS AND DISCUSSION}

On the $16^{\text {th }}$ day the intestinal mucosa is covered by pseudostratified epithelium and the lumen was narrow, slit-like, or missing. Epithelial cells with a plane surface without microvilli and with irregular protrusions of apical membrane were visible (Fig. 1). From the $17^{\text {th }}$ day the epithelium underwent intensive rebuilding with the formation of primitive folds ${ }^{1,2}$. At the same time the groups of cells on the tips of folds released from the epithelium (Fig. 2). The folds resembled by their form non-differentiated intestinal villi, whereas in the small intestine from the $19^{\text {th }}$ day we observed typical primitive villi ${ }^{1}$. In the colon the first crypts originated on the $19^{\text {th }}$ day (Fig. 2). In accordance with the formation of primitive folds, villi and crypts we observed some signs of cell death including apoptotic bodies (Fig. 3). We observed strong positivity

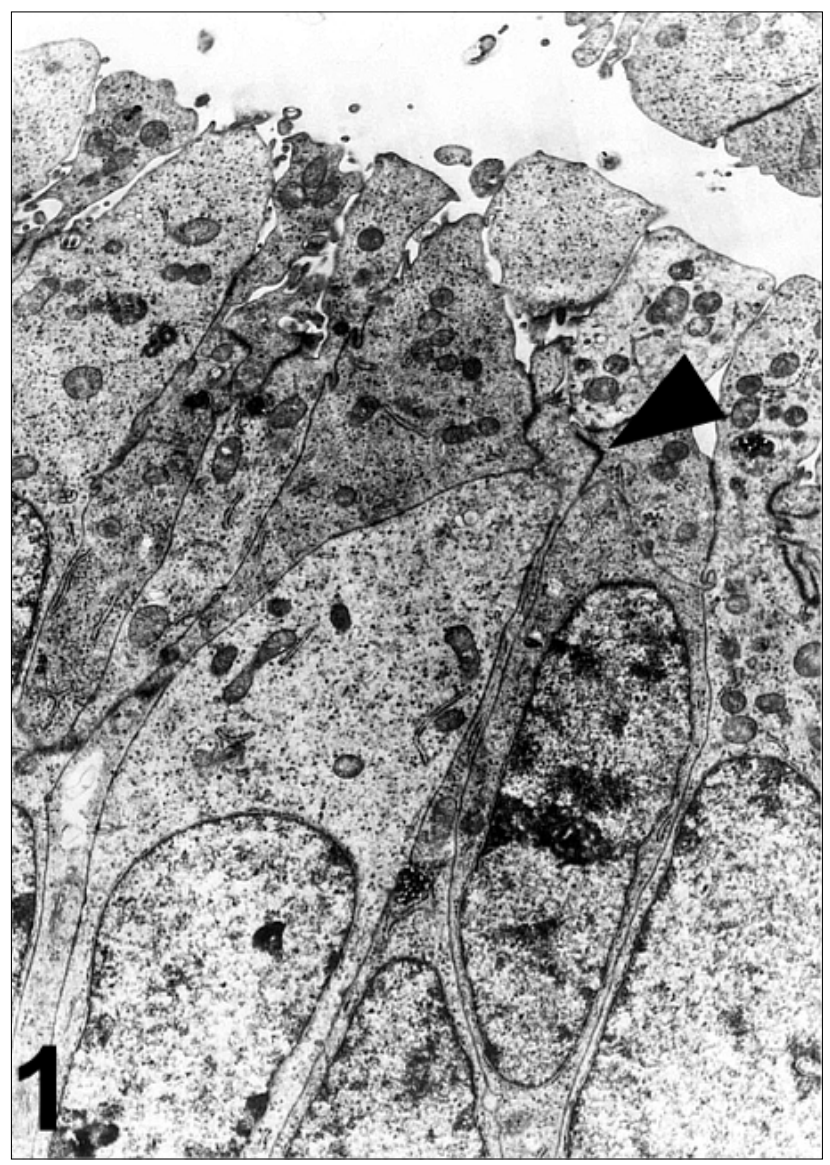

Fig. 1. 16-day old rat colon; the junctional complexes only in the apical region of cells (arrow), the protrusions of apical cell membranes; $7700 \mathrm{x}$. 


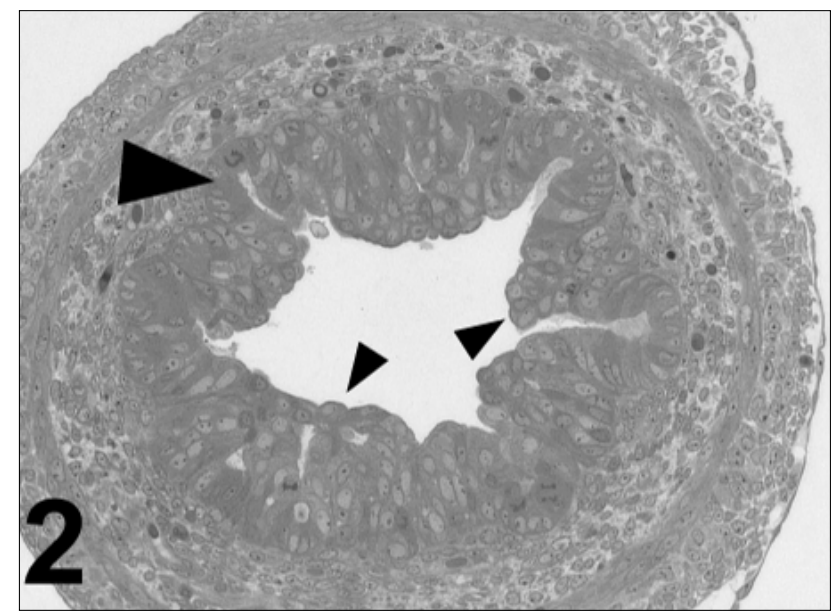

Fig. 2. 19-day old rat colon; primary folds, small group of eliminated cells (small arrows), first primitive crypts (arrow); semithin section $40 \mathrm{x}$.

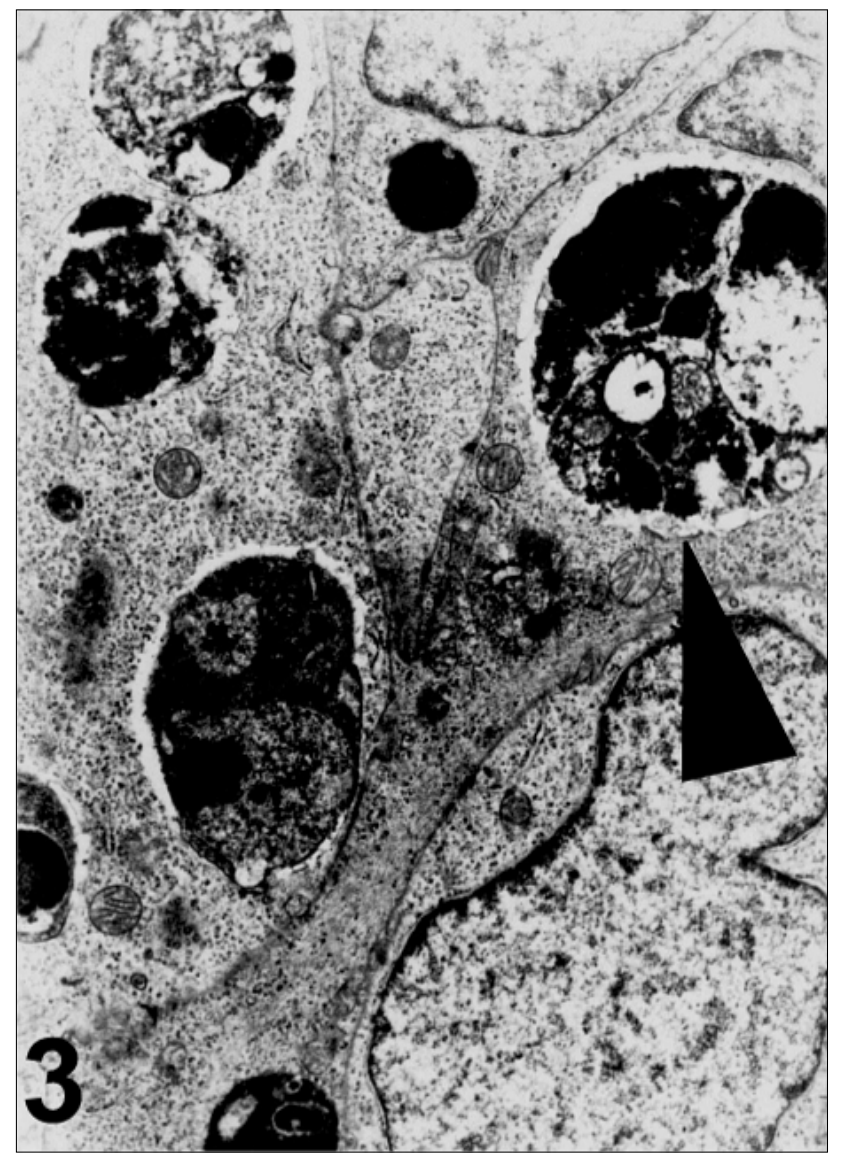

Fig. 3. Colon of 18-day old rat; fagocytosed apoptotic bodies (arrow); $10000 \mathrm{x}$.

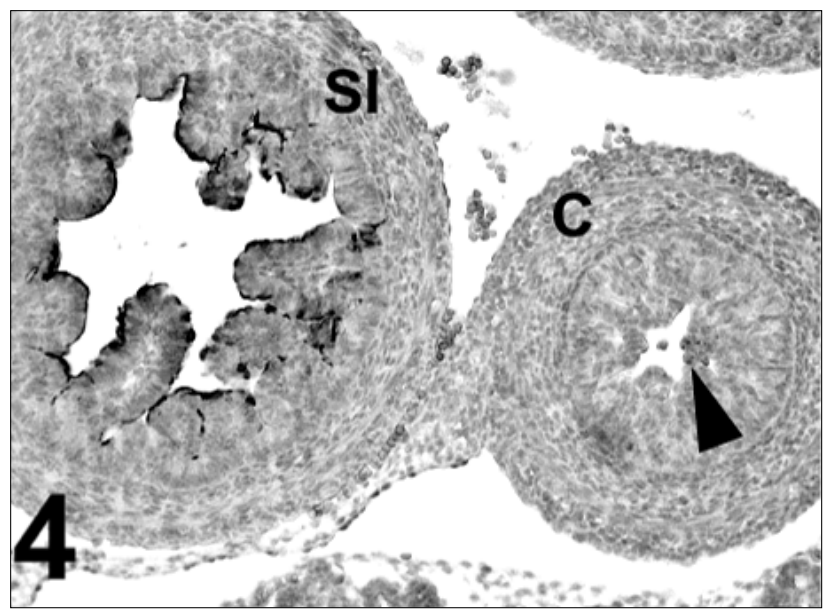

Fig. 4. Caspase-3, 19-day old rat; colon (C) - positive deposits in the cells separated from the epithelium (arrow), small intestine (SI) - positivity on the apical region of primitive villi; $40 \mathrm{x}$.

for caspase- 3 from the $17^{\text {th }}$ day on the luminal surface of the small intestine. In the colon, positive findings of caspase-3 were detected in the former small deposits (Fig. 4). On the basis of these results we can confirm a partial participation of apoptosis in programmed cell death during the prenatal formation of intestinal mucous membrane.

\section{ACKNOWLEDGEMENTS}

Supported by the Research Projects of Ministry of Education of Czech Republic No. 111100005.

\section{REFERENCES}

1. Vagnerová R. (1991) Diferenciace embryonálního epitelu tenkého střeva u krysy. Plzeň. Lék. Sborník, Suppl. 63: 331-332.

2. Vagnerová R. (2003) Prenatal differentiation of rat intestinal epithelium. International Participation, Hradec Králové 15-16. 9. Abstracts: 75. 